\title{
International Solidarity and the Global Compact on Refugees: What Role for the African Union and the European Union?
}

\author{
Salvatore F Nicolosi* \\ Utrecht University, Utrecht, The Netherlands \\ s.nicolosi@uu.nl
}

Solomon Momoh**

Utrecht University, Utrecht, The Netherlands

momoh@unhcr.org

\begin{abstract}
On the 70th anniversary of the UN Refugee Convention, this article examines the concept of solidarity and explains its relevance today, through the lens of the Global Compact on Refugees (GCR). While stressing the potential as well as the challenges for thorough implementation of the solidarity mechanisms established by the GCR, the article argues that regional organizations may contribute to meeting the GCR objectives. This is particularly urgent for regions that are most affected by migratory flows. In proposing new ways of approaching the concept of solidarity, the article suggests that the African Union strengthen mechanisms other than the physical sharing of refugees, including pooling resources to support states experiencing large influxes of refugees. In addition to a system of financial support for refugee protection, the article also recommends that the European Union ensures safe channels for arrivals and a more robust resettlement programme, to help realize the GCR objectives.
\end{abstract}

\footnotetext{
* Assistant professor, Utrecht University; researcher, Utrecht Centre for Regulation and Enforcement in Europe (RENFORCE).

** PhD, Utrecht University; protection associate, UN High Commissioner for Refugees (UNHCR), Nigeria.

The opinions expressed in this article are those of the authors. They do not purport to reflect the opinions or views of the UNHCR. The authors wish to acknowledge the support by the UNHCR senior development officer, Regional Bureau for West and Central Africa and the RENFORCE research assistant. While the article is the product of joint research, each author contributed different sections, but wrote the introduction and conclusions jointly. In particular, Dr Momoh wrote the sections on restructuring solidarity in the 2018 Global Compact on Refugees and on the African Union; and Dr Nicolosi wrote the sections on solidarity in the normative set-up of the UN Refugee Convention and on the European Union.
} 


\section{Keywords}

Global Compact on Refugees, solidarity, responsibility sharing, African Union, European Union

\section{INTRODUCTION: THE QUEST FOR SOLIDARITY IN REFUGEE PROTECTION}

With the increasing number of refugees globally, ${ }^{1}$ international solidarity has become all the more urgent to ensure an adequate response to the challenges of refugee protection. ${ }^{2}$ Quests for solidarity, in the context of responsibilitysharing, ${ }^{3}$ have been high on political agendas, ${ }^{4}$ especially in the aftermath of the migratory emergency triggered, inter alia, by the civil war in Syria, ${ }^{5}$ terrorism $^{6}$ and political tension in parts of Africa and elsewhere. ${ }^{7}$ Although the

1 According to the most recent UNHCR statistics, there were more than 26 million refugees in the world in 2020: "Refugee data finder" (UNHCR), available at: <https://www. unhcr.org/refugee-statistics/> (last accessed 13 December 2021).

2 See M Foster "The implications of the failed 'Malaysian solution': The Australian High Court and refugee responsibility sharing at international law" (2012) 13 Melbourne Journal of International Law 1.

3 While the concept of "responsibility-sharing" is often used interchangeably with the concept of "burden-sharing", this article takes the viewpoint of "responsibility-sharing" as opposed to "burden-sharing". This is because, while the concept of responsibilitysharing uses a rights-based approach, the concept of "burden-sharing" views international cooperation from the viewpoint of a "burden", ie the transfer of a burden rather than transfer of responsibility.

4 See, for example, the declaration by former UNCHR António Guterres in his first press conference in 2017 after becoming UN Secretary-General: "Heading to Uganda for 'solidarity summit,' UN chief marks World Refugee Day with calls for action” (20 June 2017), available at: <https://news.un.org/en/story/2017/06/559932-heading-uganda-sol idarity-summit-un-chief-marks-world-refugee-day-calls-action> (last accessed 13 December 2021); also see former European Commission President Jean-Claude Juncker "State of the union 2015: Time for honesty, unity and solidarity" (9 September 2015), available at: <https://ec.europa.eu/commission/presscorner/detail/en/SPEECH_15_5614> (last accessed 13 December 2021).

5 According to the UNCHR, over 5.6 million people have fled Syria since 2011, seeking safety in Lebanon, Turkey, Jordan and beyond: "Syria emergency" (UNHCR), available at: <https://www.unhcr.org/syria-emergency.html> (last accessed 13 December 2021).

6 For instance, Boko Haram terrorists have caused hundreds of thousands of Nigerian refugees to flee into neighbouring countries: "Forced displacement by the Boko Haram conflict in the Lake Chad region" (June 2016, UNHCR and World Bank) at 13; L Hammond "Somali refugee displacements in the near region: Analysis and recommendations" (paper for the UNHCR Global Initiative on Somali Refugees) at 6, available at: <https:// www.unhcr.org/55152c699.pdf> (last accessed 13 December 2021).

7 Since 2016, Nigeria has received over 70,000 Cameroonian refugees fleeing the armed conflict between the Cameroonian government and the Ambazonian separatist group: "Cameroon situation in Nigeria: Responding to the needs of IDPs and Cameroonian refugees in Nigeria" (UNHCR supplementary appeal January - December 2019) at 3, available at: <https://reporting.unhcr.org/sites/default/files/UNHCR\%20Cameroon\%202019\% 20Supplementary\%20Appeal\%20\%28March\%202019\%29.pdf> (last accessed 13 December 
exact nature of the responsibility-sharing norm in international law is unclear, ${ }^{8}$ the adoption in 2018 of the Global Compact on Refugees (GCR) ${ }^{9}$ has to a large extent provided some clarity on how the concept of solidarity can be construed by equitably distributing the world's refugees among states through different responsibility-sharing tools. The GCR advises that pledges and contributions to be made at the Global Refugee Forum, could take different forms, including financial, material and technical assistance. ${ }^{10}$

The quest for solidarity in international refugee law is not new ${ }^{11}$ and has generated a thriving academic debate over the years. ${ }^{12}$ Great expectations have also been generated by the GCR regarding a universal system of responsibility-sharing. ${ }^{13}$ The harsh reality is that the paradigm of international solidarity has yet to materialize into solid obligations. The GCR is a promising political project, but its legal commitments remain "thin". ${ }^{14}$ Departing from such an "illusory" 15 quest for universal solidarity, this article argues that the paradigm of responsibility-sharing in the CGR could result in significant binding obligations, if effectively integrated within regional refugee regimes. These could, in fact, provide the institutional structures as well as binding legal frameworks that the international refugee regime has lacked from the start. Two regions that are particularly affected by migratory flows (Africa and Europe) have also favoured legal forms of integration that are significantly advanced in the field of refugee protection. Despite differences in their political, socio-economic and cultural contexts, both regions show great potential to contribute to the debate on the understanding of solidarity as an essential feature for the future sustainability of the international regime for refugee protection.

contd

2021). See also "Ethiopia refugee crisis" Voice of America, available at: "https://www.voanews. com/ethiopian-refugee-crisis> (last accessed 13 December 2021).

8 See $\mathrm{P}$ Wall "A new link in the chain: Could a framework convention for refugee responsibility sharing fulfil the promise of the 1967 protocol?" (2017) 29 International Journal of Refugee Law 201 at 207.

9 The GCR was adopted by UN General Assembly (UNGA) resolution (17 December 2018), UN doc A/RES/73/151. See "The Global Compact on Refugees" (UNHCR), available at: <https://www.unhcr.org/the-global-compact-on-refugees.html> (last accessed 13 December 2021).

10 Id, para 18. For more detail about the Global Refugee Forum, see note 44 below.

11 See UNHCR Executive Committee "International solidarity and refugee protection", conclusion no 52 (XXXIX) (10 October 1988).

12 See for example, OC Okafor "Cascading toward 'de-solidarity'? The unfolding of global refugee protection” (Third World Approaches to International Law Review Reflections \#2/2019).

13 TA Aleinikoff and L Zamore The Arc of Protection: Reforming the International Refugee Regime (2019, Stanford University Press) at 118-28.

14 See the critique by J Hathaway "The global cop-out on refugees" (2018) 30 International Journal of Refugee Law 591.

15 Id at 592. 
In this connection, this article pursues a twofold goal. First, it aims to explain the particular meaning of solidarity given in the regional systems of refugee protection established by the African Union (AU) and the European Union (EU). Secondly, the research aims to illustrate how the paradigm of cooperation and responsibility-sharing set out in the GCR can be integrated within these regional systems.

To pursue this twofold aim, the article first reflects on the reconceptualization of solidarity, especially in its constitutive element of responsibilitysharing, from the start of the international refugee regime to the model established by the GCR. This shows the two-pronged nature of the principle of solidarity in international refugee law, consisting of both prescriptive and operational dimensions. Secondly, the focus shifts to the regional level, by critically discussing how the EU and the AU regimes connect with the notion of international solidarity. This will help address the opportunities and challenges for these regional systems to be at the forefront of effective refugee protection in the light of the GCR.

More specifically, the research examines the concept of African solidarity and how it has fared since the adoption of the 1969 Convention Governing the Specific Aspects of Refugee Problems in Africa by the Organisation of African Unity (OAU Convention). ${ }^{16}$ It analyses African solidarity beyond the physical sharing of refugees between states. It sheds light on the need for African states to view the idea of solidarity with refugees from the perspective of providing or pooling financial resources to support states hosting refugees, as countries in the EU have, to a certain extent, already been doing and in line with one of the main objectives of the GCR, namely to ease pressures on host countries. After all, the African Charter on Human and Peoples' Rights provides in article 21(4) that "States parties ... shall individually and collectively exercise the right to free disposal of their wealth and natural resources with a view to strengthening African unity and solidarity". ${ }^{17}$

With regard to the EU, the article argues that solidarity has to be considered as a core principle of the European integration process that determines mutual obligations for member states. These obligations are contextualized by discussing, also through the lens of case law from the Court of Justice of the EU (CJEU), recent attempts to embed a responsibility-sharing mechanism within the Common European Asylum System (CEAS). ${ }^{18}$ This helps explain the obligations stemming from article 80 of the Treaty on the Functioning of the EU (TFEU), which expressly mandates that the policies on border checks,

1610 September 1969,1001 UNTS 45.

1727 June 1981, CAB/LEG/67/3 rev 5.

18 CEAS is understood to be an integrated body of legislative instruments, including the following binding acts: reg 604/2013 [2013] OJ L180/31 (Dublin III Regulation); reg 603/2013 [2013] OJ L180/1 (Eurodac Regulation); directive 2011/95 [2011] OJ L337/9 (Qualification Directive); directive 2013/33 [2013] OJ L180/96 (Reception Directive); and directive 2013/32 [2013] OJ L180/249 (Procedures Directive). 
immigration and asylum "shall be governed by the principle of solidarity and fair sharing of responsibility, including its financial implications, between the Member States". ${ }^{19}$

As a result, while criticizing the weak legal blueprint of the GCR, this article proposes a fundamental paradigm-shift, suggesting that, if coupled with brave political imagination, ${ }^{20}$ regional actors can play a crucial normative role in enhancing solidarity and responsibility-sharing in refugee protection.

\section{SOLIDARITY AS A DISTINCT FEATURE OF INTERNATIONAL REFUGEE LAW}

The discourse on solidarity is not unique to international refugee law, as its first prominent usage arose in the context of contributions to the North Atlantic Treaty Organization (NATO). ${ }^{21}$ Additionally, the notion of solidarity is implicitly embedded in the UN. Article 1(3) of the UN Charter ${ }^{22}$ provides that achieving international cooperation on solving "international problems of an economic, social or humanitarian character" is among the UN's overarching purposes. Article 56 of the UN Charter obliges states to "take joint and separate action in cooperation" with the UN. ${ }^{23}$

In the field of refugee protection, while the concept of solidarity has been persistently invoked, it remains "complex, multi-dimensional and normative". ${ }^{24}$ Boswell notes that the notion of solidarity, mainly understood as "burden-sharing" or "responsibility-sharing" has a chequered history. Since the 1950s, the concept has developed as a "principle for promoting international cooperation among states receiving refugees", ${ }^{25}$ especially in situations where there is a mass influx of asylum seekers. ${ }^{26}$ From this perspective, the preamble to the 1951 UN Refugee Convention (UN Refugee Convention $)^{27}$ clearly states that granting asylum "may place unduly heavy

19 TFEU consolidated version [2016] OJ C202/1.

20 M Ticktin "Thinking beyond humanitarian borders" (2016) 83 Social Research 255.

21 AC Flores "Reconceiving 'burden-sharing' in international refugee law" (2016) 7 The King's Student Law Review 40 at 41.

2224 October 1945, 1 UNTS XV.

23 V Türk and M Garlick "From burdens and responsibilities to opportunities: The Comprehensive Refugee Response Framework and a Global Compact on Refugees" (2016) 28/4 International Journal of Refugee Law 656 at 658.

24 H Bauder and L Juffs "'Solidarity' in the migration and refugee literature: Analysis of a concept" (2020) 46 Journal of Ethnic and Migration Studies 46 at 46.

25 C Boswell "Burden-sharing in the new age of immigration" (1 November 2003) Migration Information Source, available at: <https://www.migrationpolicy.org/article/burdensharing-new-age-immigration> (last accessed 13 December 2021). For further references, see A Hurwitz The Collective Responsibility of States to Protect Refugees (2009, Oxford University Press).

26 AV Eggli Mass Refugee Influx and the Limits of Public International Law (2002, Martinus Nijhof).

27 UN Convention Relating to the Status of Refugees (28 July 1951) UNTS, vol 189 at 137. 
burdens on certain countries", thereby acknowledging the need to foster international cooperation for sharing responsibility for hosting refugees. In an attempt to substantiate the concept of solidarity in refugee protection, Martins notes that "solidarity establishes that States have an obligation to share the responsibility of finding durable solutions for refugees who have been deprived of a community". ${ }^{28}$ This clearly captures the essence of the international paradigm of solidarity: while at the prescriptive level the concept needs to be predicated in favour of the refugees (solidarity with the refugees) in order to find adequate solutions for their safety, at the operational level it requires states to be cooperative (solidarity among states) in assisting states hosting refugees with effective responsibility-sharing mechanisms.

This two-pronged approach to solidarity is common in regional systems. For instance, as explained in greater detail below, in the African context, solidarity could broadly mean "African humanism" as a "philosophy of compassion, community and solidarity". ${ }^{29}$ In the EU, Advocate General Sharpston recently clarified that solidarity "requires one to shoulder collective responsibilities ... burdens to further the common good". ${ }^{30}$

However, while numerous international instruments stress the need for international solidarity to refugees and cooperation among states, ${ }^{31}$ not much has been achieved. ${ }^{32}$ In an attempt to shed some light on the evolution and understanding of the concept of solidarity in international refugee law, this section elaborates on the practice of international refugee law from the UN Refugee Convention until the recent GCR.

28 G Martin "International solidarity and co-operation in assistance to African refugees: Burden-sharing or burden-shifting” (1995) 7 International Journal of Refugee Law 250 at 253.

29 BE Winks "A covenant of compassion: African humanism and the rights of solidarity in the African Charter on Human and Peoples' Rights" (2011) 11 African Human Rights Law Journal 447 at 456.

30 CJEU joined cases C-715/17, C-718/17 and C-719/17 Commission v Poland, Hungary, Czech Republic, opinion of Advocate General Sharpston (31 October 2019), para 253.

31 See, inter alia, UNGA Resolution on the UN Millennium Declaration, UN doc A/RES/55/2 (2000), art 6; UNGA Resolution on Promotion of a Democratic and Equitable International Order, UN doc A/RES/56/151 (2001), res 3(f); UNGA Resolution on the Promotion of a Democratic and Equitable International Order, UN doc A/RES/57/213 (2002), res 4(e)-(f); UNGA Resolution on the Promotion of a Democratic and Equitable International Order, UN doc A/RES/59/193 (2004), res 4(e)-(f); UNHCR Executive Committee conclusions nos 89(LI) (2000), 11(XXIX) (1978), 22 (XXXII) (1981), 52(XXXIX) (1998), 15(XXX) (1979), 77(XLVI) (1995), 79(XLVII) (1996), 80(XLVII) (1996), 85(XLIX) (1998), 87 (L) (1999), 89 (LI) (200), 90 (LII) (2001), 100 (LV) (2004) and 112 (LXVII) (2016); OAU Convention; Organization of American States Cartagena Declaration on Refugees (1984); F Grandi "High-level meeting on global responsibility sharing through pathway for admission of Syrian Refugees: High Commissioner's closing remarks, Geneva, 30 March 2016", available at <https://www.unhcr.org/admin/hcspeeches/56fc0e018/highlevel-meeting-global-responsibility-sharing-pathway-admission-syrian.html> (last accessed 15 December 2021).

32 V Türk "Prospects for responsibility sharing in the refugee context" (2016) 4 Journal on Migration and Human Security 45 at 48. 


\section{Solidarity in the normative set-up of the UN Refugee Convention}

The concept of solidarity in relation to refugees has been present since the start of the international refugee protection regime. Recital 4 of the UN Refugee Convention provides for international cooperation in order to handle refugee situations across the world. The issue of international support to relieve the "burden" on states receiving large numbers of refugees was initially considered for inclusion in the operative part of the convention. The proposal was to link it to the question of admission of refugees to consolidate the provision in article 14 of the Universal Declaration of Human Rights on the right to seek and enjoy asylum. ${ }^{33}$

Over the years, and even before the adoption of the GCR, the UNHCR has stressed the role of solidarity in refugee protection also with a view to finding durable solutions for refugees. ${ }^{34}$ As emphasized by Boswell, since the adoption of the UN Refugee Convention, solidarity, in its constitutive element of burden- or responsibility-sharing, has been interpreted as requiring two main sorts of actions. The first has been providing financial assistance for countries of asylum, usually less developed states, to help them with the care and maintenance of refugees, mainly through funding the activities of the UNHCR in these countries. The second type of actions has involved "physical" as opposed to financial burden-sharing, ie the distribution of refugees among states. ${ }^{35}$

Through the mandate in its statute ${ }^{36}$ and the provisions of the UN Refugee Convention, the UNHCR has encouraged and supported states in implementing the principle of responsibility-sharing by way of local integration, ${ }^{37}$ voluntary repatriation and resettlement, ${ }^{38}$ together referred to as "durable solutions". According to the UNHCR, a durable solution is one that ends the

33 C Inder "The origins of 'burden sharing' in the contemporary refugee protection regime" (2017) 29 International Journal of Refugee Law 523 at 532. See also, "Ad Hoc Committee on Statelessness and Related Problems, status of refugees and stateless persons: Memorandum by the Secretary-General" (3 January 1950, UN Economic and Social Council), available at: <https://www.unhcr.org/protection/statelessness/3ae68c280/adhoc-committee-statelessness-related-problems-status-refugees-stateless.html> (last accessed 13 December 2021).

34 As reported in Türk and Garlick "From burdens and responsibilities", above at note 23 at 662, at the Congress on International Solidarity and Humanitarian Actions organized by the International Red Cross and UNHCR in 1980, former UNHCR Poul Hartling noted: "There is hardly a single subsequent resolution of the General Assembly of the United Nations relating to the work of my Office which does not contain some reference to the importance of international solidarity in seeking solutions to the refugee problem". See also P Hartling "International solidarity and the international protection of refugees" in Congress on International Solidarity and Humanitarian Actions (1980, International Institute of Humanitarian Law) 237.

35 Boswell "Burden-sharing in the new age", above at note 25.

36 Statute of the Office of the UNHCR, UNGA res 428(V) (14 December 1950).

37 UN Refugee Convention, art 34.

38 See UNGA res $428(\mathrm{~V})$, above at note 36 , art 2. See also Statute of the Office of the UNHCR, arts 8 and 9 . 
problems associated with displacement and allows people to resume their normal lives in a safe environment. ${ }^{39}$ In order to foster a more reliable and effective international response and ensure greater equity in the sharing of responsibilities, in 2002 the UN High Commissioner for Refugees (UNHCR) launched a process of global consultations on international protection, which gave particular attention to improving protection tools. These consultations led to the development of the Agenda for Protection, which gave rise to the Framework for Durable Solutions for Refugees and Persons of Concern (Framework for Durable Solutions), among other initiatives. ${ }^{40}$

According to the UNHCR, ${ }^{41}$ the Framework for Durable Solutions proffers models for improved targeting of development assistance for refugees through initiatives known as: Development Assistance for Refugees; Repatriation, Reintegration, Rehabilitation and Reconstruction; and Development through Local Integration, based on broad-based partnerships between governments and humanitarian and development actors. Durable solution arrangements have used both as a protection tool, as well as a tool for responsibility-sharing by states with the support of UNHCR even before the formal Framework for Durable Solutions was developed in 2003.

In its Millennium Declaration the UN General Assembly (UNGA) provided a further boost to the need for international solidarity, by stating, inter alia, that global challenges must be managed in a way that distributes the costs and burdens fairly in accordance with basic principles of equity and social justice. In other words, "those who suffer or who benefit least deserve help from those who benefit most". ${ }^{42}$ While this statement does not specifically mention refugees or asylum seekers, with over 70 million people forcibly displaced worldwide, ${ }^{43}$ it is safe to say that responsibility-sharing and solidarity with regard to the global displacement problem is essential to international relations in the 21st century. There have been many impressive instruments and initiatives geared towards responsibility-sharing both at international and regional levels. However, due to the ever-increasing number of displaced persons worldwide, a reduction in financing for refugee operations and an increasing number of states refusing to accept refugees, the need to find a more specific and coordinated platform for international solidarity has become ever more pressing. ${ }^{44}$

39 UNHCR E International Protection: A Protection Induction Programme (2006, UNHCR) at 72.

40 Finding Durable Solutions: UNHCR Global Appeal 2006 (2006, UNHCR) at 23.

41 "Local integration and self-reliance" (2 June 2005, UNHCR), doc EC/55/SC/CRP.15, available at: <https://www.refworld.org/docid/478b3ce12.html> (last accessed 13 December 2021).

42 UNGA "United Nations Millennium Declaration" (18 September 2000), UN doc A/RES $/ 55 / 2$.

43 "Figures at a glance" (UNHCR), available at: <https://www.unhcr.org/figures-at-a-glance. html> (last accessed 13 December 2021).

44 Before the adoption of the Comprehensive Refugee Response Framework, adopted in the GCR, there was no formal platform for coordinating support and responsibility-sharing 


\section{Restructuring solidarity in the 2018 Global Compact on Refugees}

A more decisive emphasis on solidarity in refugee protection was initiated in 2016 by the UNGA hosting a high-level Summit for Refugees and Migrants that aimed to improve the way in which the international community responds to large movements of refugees and migrants. As a result, all $193 \mathrm{UN}$ member states unanimously adopted the New York Declaration for Refugees and Migrants (New York Declaration), ${ }^{45}$ committing themselves to a more equitable sharing of responsibility for hosting and supporting the world's refugees, while taking account of existing contributions and states' different capacities and resources.

The New York Declaration has been described as a milestone for global solidarity and refugee protection at a time of unprecedented displacement. ${ }^{46}$ The commitments that member states agreed reflect that the "protection of those who are forced to flee, and support for the countries that shelter them, are a shared international responsibility - a responsibility that must be borne more equitably and predictably". ${ }^{47}$ The New York Declaration called on UNHCR to initiate and lead the development of a Comprehensive Refugee Response Framework (CRRF) in close coordination with relevant states, including host countries, and involving other relevant UN entities, for each situation involving large refugee movements. ${ }^{48}$ Through the declaration, states also agreed to continue to improve international responses by working towards a global compact on refugees. This was achieved with the adoption of the GCR on 17 December 2018. Although non-binding, the GCR reflects the political will of state parties to enhance cooperation and solidarity with both refugees and their host communities. Betts notes that, "since the creation of the modern refugee system, there has been a disjuncture between a strongly institutionalized norm of 'asylum' and a weakly institutionalized norm of 'responsibility sharing'”. ${ }^{49}$ The GCR addresses this gap in international refugee protection.

contd

in the refugee context. Although state support is discretionary, even under the current GCR, it has however introduced an avenue for states to make commitments through the Global Refugee Forum where states come together to make pledges.

453 October 2016, UN doc A/RES/71/1.

46 K Gastorn "The 2016 New York Declaration, the CRRF, and the 2018 Global Compact on Refugees" (presentation at the stakeholders' meeting on global compact on refugees, Jacaranda Hall 1, India Habitat Center, Lodhi Road, Delhi, 29 September 2017), available at: <http://www.aalco.int/Global\%20Compact\%20on\%20Refugees.pdf> (last accessed 13 December 2021); see also E Ferris and KM Donato Refugees, Migration and Global Governance: Negotiating the Global Compacts (2019, Routledge) at 113.

47 UNHCR "Comprehensive refugee response framework: From the New York Declaration to a global compact on refugees" (5 December 2016), available at: <https://www.refwo rld.org/docid/589332a90.html> (last accessed 13 December 2021).

48 See New York Declaration, annex 1, para 2.

49 A Betts "The Global Compact on Refugees: Towards a theory of change?" (2018) 30 International Journal of Refugee Law 623 at 623. 
The GCR acknowledges that countries that receive and host refugees, often for extended periods, make an immense contribution from their own limited resources to the collective good, and indeed to the cause of humanity. Accordingly, the GCR stresses the need for such countries to receive tangible support from the international community as a whole in leading the response. ${ }^{50}$ This takes into account that there is no clear obligation for non-refugee-hosting countries. ${ }^{51}$

The GCR's objectives are manyfold and embody the sense of solidarity that must permeate international refugee law. The GCR aims to ease the pressures on host countries, particularly low and middle-income countries, through contributions from other states and relevant stakeholders; 52 it enhances refugee self-reliance, expands opportunities for refugees to access, as appropriate, education, healthcare and services, livelihood opportunities and labour markets, without discriminating among refugees and in a manner that also supports host communities; 53 it aims to expand access to third country solutions, by expanding resettlement places and complementary pathways for admission to third countries; ${ }^{54}$ and, finally, it supports conditions in countries of origin for a safe and dignified return, by providing development assistance to countries of origin, in line with the 2030 Agenda for Sustainable Development and other relevant frameworks. ${ }^{55}$

The GCR, therefore, "emanates from fundamental principles of humanity and international solidarity, and seeks to operationalize them through responsibility-sharing to better protect and assist refugees and support host countries and communities". ${ }^{56}$ Moreover, the GCR adds a few new initiatives to the concept of international solidarity. These include the Global Refugee Forum, arrangements to support a specific refugee situation, and proposed key tools for effecting burden- and responsibility-sharing. ${ }^{57}$ These initiatives provide the necessary mechanisms to galvanize international support and solutions for large-scale displacements across the world. ${ }^{58}$

Despite its innovations, in the absence of legally binding arrangements, the effectiveness of the GCR's mechanisms is, nonetheless, questionable. ${ }^{59}$ This opens the possibility that more effective solutions to strengthen the sense of solidarity in international refugee law can be achieved at the regional level

50 GCR, para A14.

51 Betts "The Global Compact on Refugees", above at note 49 at 623.

52 GCR, para 50.

53 Id, para $13 \mathrm{~b}$.

54 Id, para 18.

55 Id at 5.

56 Id at 2, para B.

57 Id at 7-48.

58 O Dare and AM Abebe "Regional solutions and the Global Compact on Refugees: The experience from Africa” (2018) 30 International Journal of Refugee Law 704.

59 See BS Chimni "Global Compact on Refugees: One step forward, two steps back" (2018) 30 International Journal of Refugee Law 630. 
through more advanced supranational regimes, as the next section illustrates in greater detail.

\section{SOLIDARITY AS A PILLAR OF REFUGEE PROTECTION AT THE REGIONAL LEVEL?}

This section assesses the concept of solidarity in the constitutive element of responsibility-sharing in the regional contexts of the AU and EU. The specific objective of this section is to appraise and compare the legal understanding of solidarity in refugee protection and the legal mechanisms in place for responsibility-sharing, and the actual application of the concept in the two regions. The aim is to make recommendations for the implementation of the major arrangements provided for by the GCR at regional level.

\section{The distinct features of African solidarity in the regional legal framework}

It has been observed that the first regional instruments for the protection of refugees in Africa arose as result of the large scale displacements following the decolonization process that swept across the continent in the 1960 s. ${ }^{60}$ Mujuzi noted that, "as early as 1964, African countries realised that some countries, such as Uganda, Burundi and Tanzania, were facing problems related to hosting refugees and that the international community was not paying sufficient attention to the problems these countries and the refugees they were hosting faced". ${ }^{61}$

Due to the heavy and unequal responsibility on a few states, there became an increasing call for solidarity to resolve the refugee problems and other challenges confronting the continent. On the one hand, this call for solidarity institutionalized the spirit of "African humanism" in the first ever regional legal framework on refugee protection, while, on the other hand, it triggered a process aimed at expanding the regional arrangements for refugee protection. These aspects are analysed below.

\section{Solidarity as an institutionalized representation of African humanism}

When the OAU was established in May 1963, African heads of state and government affirmed in the Charter of the OAU, inter alia, that the purpose of the OAU (now the AU), was to promote the unity and solidarity of African states, coordinate and intensify their cooperation and efforts to achieve a better life for the peoples of Africa. ${ }^{62}$ Even before the enactment of the OAU Convention in 1969 , solidarity in the African context has broadly symbolized

60 See "Burden-sharing: Discussion paper submitted by UNHCR fifth annual plenary meeting of the APC" (UNHCR), available at: <https://www.iom.int/jahia/webdav/ site/myjahiasite/shared/shared/mainsite/policy_and_research/rcp/APC/2000-DiscussionPaper-UNHCR-submission-5th-plenary.pdf> (last accessed 13 December 2021).

61 J Mujuzi “The African Commission on Human and Peoples' Rights and the promotion and protection of refugees' rights" (2009) 9 African Human Rights Law Journal 160 at 162. 
"African humanism". ${ }^{63}$ As emphasized by Winks, "the solidarity rights rather represented an African emphasis on fraternity, reciprocity and compassion. African humanism has been applied in practice as a viable and valuable legal philosophy". 64

While most African states became party to the UN Refugee Convention shortly after gaining their independence, many soon began to "express increased dissatisfaction that the international refugee instruments did not reflect the realities of the refugee situation in Africa". ${ }^{65}$ This necessitated the inclusion of a provision on responsibility-sharing and solidarity in the OAU Convention, which is the legal basis of the concept in the African refugee context. Specifically, the OAU Convention provides:

"Where a Member State finds difficulty in continuing to grant asylum to refugees, such Member State may appeal directly to other Member States and through the OAU, and such other Member States shall in the spirit of African solidarity and international cooperation take appropriate measures to lighten the burden of the Member State granting asylum.”66

This provision creates a level of obligation on member states in the spirit of "African solidarity" to "endeavour to ease the burden of some of their members who have difficulty in coping with the refugees crossing their borders" ${ }^{67}$

The principle of responsibility-sharing can also be inferred from the expansion of the definition of "refugee" in the OAU Convention to cover "external aggression, occupation, foreign domination or events seriously disturbing public order in either part or the whole of his country of origin or nationality". 68 Wood noted that:

"[B]y extending refugee protection on the African continent beyond persons with a well-founded fear of persecution, to those fleeing more widespread and generalized forms of harm, such as political unrest, civil war, and even natural disaster, the expanded refugee definition has been praised for its liberal and humanitarian nature, for being 'more realistic about the nature of contemporary refugee scenarios' and for depoliticizing asylum by allowing states

63 “... in the spirit of African solidarity, every African country had the duty to assist freedom fighters fighting for the liberation of the African continent from colonial or racial domination": MR Rwelamira "Two decades of the 1969 OAU Convention governing the specific aspects of the refugee problem in Africa" (1989) 1 International Journal of Refugee Law 557 at 559.

64 Winks "A covenant of compassion", above at note 29 at 447-48.

65 J Milner Refugees, the State and the Politics of Asylum in Africa (2009, Palgrave Macmillan) at 22.

66 OAU Convention, art 2(4).

67 G Martin "International solidarity and co-operation in assistance to African refugees: Burden-sharing or burden-shifting” (1995) 7 International Journal of Refugee Law 250 at 259.

68 OAU Convention, art 1(2). 
to recognize refugees 'without implicitly accusing another government of being persecutory". 69

In addition to sharing the responsibility for hosting refugees, the application of the OAU Convention's definition removes the complexities associated with the definition in the UN Refugee Convention and makes it easy for African countries to share in solidarity and alleviate the burden faced by neighbouring countries, which may not be captured by the definition enshrined in the UN Refugee Convention. In the emerging discourse of the concept of "climate refugees", the aspect of "events seriously disturbing public order" in the OAU Convention could be ripe for exploration in the African context.

Nonetheless, this institutionalized representation of African humanism and solidarity has been challenged by the evolution of refugee policies in postindependence Africa. In fact, while initially, between the early 1960s and 1990, African countries generously welcomed refugees through an "open door policy", from the 1990s onwards the commitment to responsibilitysharing was replaced by protection fatigue. ${ }^{70}$ Many refugee-hosting countries in Africa began to express domestic concerns, ranging from internal security to infrastructural and environmental concerns. These included: fear that refugees coming from civil war situations may bring weapons into their host countries; strains on socioeconomic resources; and the depletion of natural resources. These aspects, coupled with limited assistance and a lack of sustained cooperation from the international community, have been noted as some of the reasons why many African states closed their borders to refugees. ${ }^{71}$ As a result, over the years, the treatment of refugees in the region began to fall below basic standards of international law. ${ }^{72}$

A progressive expansion of regional arrangements for responsibility-sharing and solidarity: A potential to implement the GCR?

Despite the protection fatigue for refugees witnessed in the 1990s, in furtherance of article II of the OAU Charter, Africa continued to register a progressive expansion of regional arrangements for responsibility-sharing and solidarity. While the "open door policy" for refugees was confronted with the huge economic realities of the period, it became clear for many African states that there was more need for international solidarity and cooperation to resolve

69 T Wood "Expanding protection in Africa? Case studies of the implementation of the 1969 African Refugee Convention's expanded refugee definition” (2014) 26 International Journal of Refugee Law 555 at 556.

70 B Rutinwa "The end of asylum? The changing nature of refugee policies in Africa" (2002) 21 Refugee Survey Quarterly 12.

71 See J Schneider "The refugee crisis in southern and central Africa" (1999) 4 Global Dialogue 1.

72 B Rutinwa "Relationship between the 1951 Refugee Convention and the 1969 OAU Convention on Refugees: A historical perspective” in V Türk, CW Wouters and A Edwards (eds) In Flight from Conflict and Violence: UNHCR's Consultations on Refugee Status and Other Forms of International Protection (2017, Cambridge University Press) 94 at 113. 
the problems confronting the continent. The need for cooperation and responsibility-sharing reignited the principle of African solidarity and humanism.

In the 1990s, even to the beginning of the 2000s, when scholars would have suggested that international cooperation and solidarity would be difficult to attain in Africa, especially due to the worsening economic climate, the spirit of African humanism and solidarity was reawakened in Africa. From western Africa to eastern Africa, new cases of large-scale displacement sprang up, with $\mathrm{AU}$ members rising to the occasion. In West Africa, Liberia and Sierra Leone produced a considerable number of refugees as a result of a brutal civil war in 1989-2002. ${ }^{73}$ The refugee situation in Liberia and Sierra Leone become a litmus test for the principle of international solidarity, responsibility-sharing and African humanism. ${ }^{74}$ A practical example on responsibility-sharing was observed in the West African sub-region in June 2007 where, in furtherance of the obligation under article 2(4) of the OAU Convention, Liberia, Sierra Leone, Nigeria, the Economic Community of West African States (ECOWAS) $)^{75}$ and UNHCR signed the Multipartite Agreement for the Local Integration of Liberian and Sierra Leonian Refugees in Nigeria. ${ }^{76}$

Before the adoption of the GCR, in addition to the OAU Convention, the subregional ECOWAS-UNHCR Memorandum of Understanding (MoU) on Equality of Treatment for Refugees with Other Citizens of Member States of ECOWAS in the Exercise of Free Movement, Right of Residence and Establishment ${ }^{77}$ was signed in 2007, which is very relevant in respect of the implementation of the GCR's regional and sub-regional approaches to responsibility-sharing. ${ }^{78}$ In addition to reemphasizing the rights of refugees from West African countries to move freely, reside and establish themselves in the territories of member states like every other West African citizen, this MoU calls on UNHCR to establish a Regional Local Integration Management Unit (RLIMU). With the MoU in place and the RLIMU established, the GCR's regional and sub-regional

73 See TM Anjum, C Nordqvist and T Timpka "The hopes of West African refugees during resettlement in northern Sweden: A 6-year prospective qualitative study of pathways and agency thoughts" (2012) 24 Conflict and Health 1.

74 This conflict saw West African states such as Nigeria, Ghana and Côte d'Ivoire hosting thousands of Liberian and Sierra Leonian refugees for more than a decade: V Nmoma "The civil war and the refugee crisis in Liberia" (1997) Journal of Conflict Studies 1 at 18. ECOWAS is one of the eight regional economic communities in Africa.

76 In the agreement, the Nigerian government committed, inter alia, to grant a set of rights to the refugees who were granted ECOWAS residence. These rights included full freedom of movement within Nigeria, the right to depart from and re-enter Nigeria (provided the holder's passport and ECOWAS residence permit remain valid), and the right to work in the formal and informal economies. See in particular para 6 of the agreement, available at: <https://www.unhcr.org/49e479ca22.pdf> (last accessed 13 December 2021).

77 Meeting of the Committee on Trade, Customs and Immigration, Accra, 25-27 September 2007.

78 See GCR, para 2.3 
approach to responsibility-sharing, especially through local integration, is effectively settled in the West African region.

Another example of the progressive expansion of regional arrangements for responsibility-sharing and solidarity in Africa following the recommendations in the New York Declaration was observed in the East Africa region with the adoption of the Nairobi Declaration on Durable Solutions for Somali Refugees and Reintegration of Returnees in Somalia. This sub-regional approach, specifically for refugees, has been described as the first of its kind, as it allows countries in the sub-region facing a refugee situation to work together to protect and find solutions for them, with support and assistance from the international community. ${ }^{79}$

\section{A two-pronged understanding of solidarity in EU asylum law}

In Europe, solidarity has been invoked over the years following the "refugee crisis" of 2015. ${ }^{80}$ In his Speech on the State of the Union in 2015, European Commission President Juncker stated clearly that, "where Europe has clearly under-delivered, is on common solidarity with regard to the refugees who have arrived on our territory". ${ }^{81}$ However, from a legal point view, to date the obligations stemming from such a principle of solidarity are not clear. ${ }^{82}$

The legal basis for solidarity is rather vague, as article 80 of the TFEU merely states that all policies in the field of border checks, asylum and migration and their implementation "shall be governed by the principle of solidarity and fair sharing of responsibility, including its financial implications, between the Member States". Scholars have pointed out that, instead of defining the scope of any legal obligations linked with article 80, EU institutions pursued a more operational approach "listing different measures that operationalize solidarity", ${ }^{83}$ including the relocation of asylum seekers throughout the EU.

79 S Carciotto and F Ferraro "Building blocks and challenges for the implementation of the Global Compact on Refugees in Africa” (2020) 8 Journal on Migration and Human Security 38 at 48 .

80 AJ Menédez "The refugee crisis: Between human tragedy and symptom of the structural crisis of European integration" (2016) 22 European Law Journal 388.

81 President of the European Commission "Authorized state of the Union address 2015: Time for honesty, unity and solidarity” (9 September 2015), available at: <https:// ec.europa.eu/info/publications/state-union-2015-european-commission-president-jeanclaude-juncker_en> (last accessed 13 December 2021).

82 I Domurath "The three dimensions of solidarity in the EU legal order: Limits of the judicial and legal approach" (2013) 35 Journal of European Integration 459 at 460.

83 E Tsourdi and P de Bruycker "EU asylum policy: In search of solidarity and access to protection” (Migration Policy Centre policy brief, May 2015) at 4, available at: <https:// cadmus.eui.eu/handle/1814/35742> (last accessed 13 December 2021). See also A Miglio "Solidarity in EU asylum and migration law: A crisis management tool or a structural principle?" in E Kuzelewska, A Weatherburn and D Kloza (eds) Irregular Migration as a Challenge for Democracy (2018, Intersentia) 23. 
Interestingly, in 2011 the European Parliament published a study on the implementation of solidarity, which, while stressing that the concept of solidarity has been left undefined in order not to limit its scope, includes a primary goal of fostering trust. ${ }^{84}$ Solidarity, in the form of responsibilitysharing, is necessary to ensure Member states' loyalty as a minimal condition of trust, because, as cases like NS $v$ UK and ME $v$ Ireland $^{85}$ have clearly illustrated, blind trust in correctly implementing legislative instruments may not be sufficient.

Therefore, solidarity constitutes the paradigm under which adequate tools need to be elaborated "to assist other Member States to reach the standards set at EU level or even to compensate for their failure to do so". ${ }^{86}$ It, therefore, entails, an axiological or prescriptive dimension as well as an operational one.

\section{Solidarity as a founding principle of EU law}

Solidarity has been referred to several times in CJEU case law as a founding principle of EU law in respect of asylum. ${ }^{87}$ In Jafari, the CJEU mentioned "a spirit of solidarity", fair cooperation and common efforts between all member states towards the management of external borders, which inform each member state's responsibility and mutual accountability for actions concerning the entry and residence of third country nationals. ${ }^{88}$

Moreover, in his lengthy opinion on the case concerning the relocation decisions brought by Slovakia and Hungary, Advocate General Bot affirmed that solidarity is among the EU's cardinal values, and a requirement that remains "at the heart of the process of integration pursued by the Treaty of Lisbon" 89

This argument was more recently echoed by Advocate General Sharpston in her opinion on the infringement procedure brought against Hungary, Poland and Czech Republic, referring back to the foundation of the "European project”, tracing from the Schuman Declaration to the EU Treaty, to emphasize further that solidarity is a founding principle of EU law. ${ }^{90}$ The advocate

84 "The implementation of article 80 TFEU on the principle of solidarity and fair sharing of responsibility, including its financial implications, between the member states in the field of border checks, asylum and immigration" (European Parliament, Directorate General for Internal Policies Policy Department C: Citizens' Rights and Constitutional Affairs Civil Liberties, Justice and Home Affairs study, April 2011), available at: <https ://www.europarl.europa.eu/thinktank/en/document/IPOL-LIBE_ET(2011)453167> (last accessed 13 December 2021).

85 CJEU joined cases C-411-10 and C-493-10 NS $v$ United Kingdom and ME $v$ Ireland (21 December 2011).

86 "The implementation of article 80", above at note 84 at 100 .

87 For a broader analysis, beyond EU asylum law, see D Schiek "Solidarity in the case law of the European Court of Justice" in H Krunke, H Petersen and I Manners (eds) Transnational Solidarity: Concept, Challenges and Opportunities (2020, Cambridge University Press) 252.

88 CJEU case C-646/16 Jafari (26 July 2017), paras 85-88.

89 CJEU joined cases C-643/15 and C-647/15 Slovakia and Hungary $v$ Council of the EU, opinion of Advocate General Bot (26 July 2017), paras 17-19.

90 CJEU joined cases C 715/17, C718/17 and C719/17 Commission v Poland, Hungary and Czech Republic, opinion of Advocate General Sharpston (31 October 2019), paras 246-48. 
general concluded that solidarity is the lifeblood of the European project, by which member states and their nationals have obligations as well as benefits, duties as well as rights, lecturing the then applicant member states that the project does not end in the benefits they can claim, but requires them to shoulder collective responsibilities and burdens to further the common good. ${ }^{91}$

The CJEU, in turn, adopted the advocate general's same line of reasoning without, however, further elaborating on the concept of solidarity. It referred to article 80 of the TFEU to reaffirm not only solidarity as a principle governing the EU's asylum policy, but also that the burden to cope with an emergency situation characterized by a sudden influx of third country nationals must therefore be divided between all member states. ${ }^{92}$ In the same sense, the CJEU affirmed that solidarity is the objective of the relocation decisions that established the emergency mechanism to relocate asylum seekers from Greece and Italy, ${ }^{93}$ thus justifying the sharing of the "burden" between all member states.

This axiological understanding of solidarity differs from the notion embedded in the AU system. The European project, in fact, mainly speaks to its member states without expressly upholding a sense of solidarity with refugees on the basis of humanitarianism. The EU notion of solidarity is more strategically political, and its prescriptive dimension can be better explained only when assessed in the light of the most recent operationalization of the principle. This can, in fact, contribute to identifying the legal obligations ensuing from such a principle.

Solidarity as a pragmatic obligation in the Common European Asylum System The CJEU's understanding of solidarity upholds a practical component to the principle, that in turn informs the existence of duties and the obligation to share burdens and responsibilities, imposed on all member states. This connects to the operational dimension of international solidarity (solidarity among states) that is inferred from the interpretation of the UN Refugee Convention. According to Advocate General Bot, cooperation and solidarity among member states are duties that must underpin the CEAS. ${ }^{94}$ Referencing articles 67(2) and 80 of the TFEU, the advocate general emphasized that solidarity is a pivotal element within the CEAS that must be "genuine and practical" and be shown towards the member states most affected by flows of asylum applicants that place disproportionate pressure on their systems. ${ }^{95}$

91 Id, para 253.

92 CJEU joined cases C 715/17, C718/17 and C719/17 Commission $v$ Poland, Hungary and the Czech Republic (2 April 2020), paras 80 and 181.

93 Id, para 180.

94 CJEU case C-213/17 X v Staatssecretaris van Veiligheid en Justitie, opinion of Advocate General Bot (13 June 2018), para 10. 
The most recent developments in EU asylum law insist on the need to operationalize solidarity. This has been pursued by adopting temporary emergency measures, namely the decisions on the relocation of asylum seekers from Greece and Italy ${ }^{96}$ and, lately, by designing permanent solidarity mechanisms to be embedded in the CEAS. While being criticized for being an unsuccessful experiment, the relocation decisions of $2015^{97}$ deserve credit for pioneering the use of emergency legislation under article 78(3) of the TFEU in the face of the sudden influx of third country nationals into certain member states, namely Greece and Italy.

In that sense, Advocate General Bot emphasized that, given the de facto inequality between member states because of their geographic situation and their vulnerability in the face of massive migration flows, the adoption of the emergency measures provided for in article 78(3) of the TFEU confers a practical content and binding nature to the principle of solidarity, ${ }^{98}$ and that the non-application of such decisions constitutes a breach of the obligation concerning solidarity and the fair sharing of responsibility expressed in article 80 of the TFEU. ${ }^{99}$ In other words, the advocate general affirmed that, in taking article 80 of the TFEU into account when interpreting article 78(3), the conclusion must be that provisional measures such as relocation decisions should allocate the burdens of solidarity between member states, in a binding fashion, ${ }^{100}$ stating that "it is the mandatory determination of the allocations per Member State which gives real scope to the principle of solidarity". ${ }^{101}$

Accordingly, in her opinion on the infringement procedure against Hungary, Poland and Czech Republic, Advocate General Sharpston reaffirmed that ensuring that the relocation mechanisms work adequately and in sufficient numbers to relieve the intolerable pressure on frontline member states "is what solidarity is about". ${ }^{102}$

Nonetheless, the operational character of solidarity in its horizontal interstate dimension does not exclude the need to construe such a principle vertically in the relationship between states and refugees. This clearly emerges from another case before the CJEU. In his opinion in Jawo, Advocate General Wathelet emphasized that the principle of solidarity and the fair sharing of responsibilities between member states must be a reality for the benefit not

96 See S Nicolosi "Emerging challenges of the temporary relocation measures under EU asylum law" (2016) European Law Review 338.

97 Council of the EU decision 2015/1523 of 14 September 2015 establishing provisional measures in the area of international protection for the benefit of Italy and Greece [2015] OJ L239/146; Council of the EU decision 2015/1601 of 22 September 2015 establishing provisional measures in the area of international protection for the benefit of Italy and Greece [2015] OJ L248/80.

98 Opinion of Advocate General Bot, above at note 89, para 242.

99 Id, paras 22-23.

100 Id, para 254.

101 Id, para 295.

102 Opinion of AG Sharpston, above at note 90, para 234. 
only of member states, but above all of the human beings concerned. This would translate into the need for member states, including national courts, to guarantee the full effectiveness of the rules, ensuring uniform minimum living conditions for the beneficiaries of international protection. ${ }^{103}$

Regrettably, this last dimension has yet to materialize. The ongoing process to reform the CEAS reflects the efforts to design a permanent inter-state solidarity mechanism for the distribution of asylum applications throughout the EU but, as illustrated in the next section, very little attention is paid to the applicants' integration into the host society, which constitutes one of the durable solutions contemplated by the GCR.

\section{The New Pact on Migration and Asylum and the Global Compact on Refugees}

Solidarity is unsurprisingly one of the main pillars of the New Pact on Migration and Asylum (New Pact) proposed by the European Commission in September 2020, which stresses that member states must be able to "rely on the solidarity of our whole European Union". ${ }^{104}$ Nevertheless, conceptually, the New Pact does not go much further than the well-known formula of solidarity already extracted from CJEU case law, as it states that responsibility must be divided between all other member states and that "all Member States should contribute". ${ }^{105}$

Scholars ${ }^{106}$ and civil society ${ }^{107}$ have already attracted fierce criticism by claiming that this political platform is all but new and definitely unfit for the "fresh start" sought by the European Commission. The question is, therefore, whether the new set of legislative proposals can favour the ambitions envisaged by the GCR at least at the European regional level.

In an attempt to ensure a more pragmatic approach, ${ }^{108}$ in the new Asylum and Migration Management Regulation ${ }^{109}$ the New Pact proposes that member states can choose either to relocate asylum seekers, to sponsor returns to help another member state repatriate irregular migrants or to provide

103 CJEU case C-163/17 Abubacarr Jawo v Bundesrepublik Deutschland, opinion of Advocate General Wathelet (25 July 2018), para 145.

104 European Commission, communication on a New Pact on Migration and Asylum, COM (2020) 609 (23 September 2020) at 1.

105 Id at 2 .

106 See, inter alia, D Thym "European realpolitik: Legislative uncertainties and operational pitfalls of the 'new' Pact on Migration and Asylum" (28 September 2020, EU Immigration and Asylum Law and Policy), available at: < http://eumigrationlawblog. eu/european-realpolitik-legislative-uncertainties-und-operational-pitfalls-of-the-new-pacton-migration-and-asylum/> (last accessed 13 December 2021).

107 "Joint statement: The Pact on Migration and Asylum: To provide a fresh start and avoid past mistakes, risky elements need to be addressed and positive aspects need to be expanded" (6 October 2020, European Council on Refugees and Exiles), available at: <https://www.amnesty.eu/wp-content/uploads/2020/10/NGO-Statement-Pact-Oct-2020FINAL.pdf> (last accessed 13 December 2021).

108 Thym "European realpolitik", above at note 106.

109 European Commission, COM (2020) 610 final. 
other types of support including external cooperation for migration management in countries of origin or transit. Such a model of mandatory but flexible solidarity can produce adverse effects, as it discourages member states from prioritizing the relocation of asylum seekers. Likewise, considering that, every year, only 40 per cent of third country nationals are effectively returned, ${ }^{110}$ few expectations are raised by the new tool of return sponsorships. Finally, instead of acting as a catalyst for a consensus, this new framework seems rather to contribute to further fragmentation in the effective management of the CEAS, neglecting that "the enjoyment of equal rights and benefits stemming from membership in the EU carries equal responsibilities". ${ }^{111}$

Scholars criticize the European Commission for having missed out on the opportunity to elaborate a true solidarity doctrine for the EU. ${ }^{112}$ If the proposal were meant to create a mechanism to balance responsibility-sharing, an even system has remained elusive. The New Pact acknowledges that member states do not have the willingness to embrace true reform of the CEAS, especially so far as it concerns member states that wanted a tougher and stricter approach to asylum and migration. Reaching a compromise between the mandatory relocation requested by frontline member states and the no-relocation demanded by the Visegrad Four (Czech Republic, Hungary, Poland and Slovakia) with the introduction of the "mandatory flexible" solidarity system is proving extremely difficult. ${ }^{113}$ This frustrates the potential of the EU to contribute effectively to the realization of the GCR objectives at the regional level. The EU has the potential to put in place the robust responsibility-sharing structures that the GCR proposes with the advantage of supporting these structures with binding obligations that can put the EU at the forefront of the management of refugee flows. However, what is needed is a paradigm shift: a change in the approach to solidarity in refugee protection that prioritizes humanitarian goals (such as resettlement schemes, safe access to the CEAS, free movement of the beneficiaries of international protection) over sterile national interests that focus on responsibility-shifts instead of solidarity.

110 See "Enforcement of immigration legislation statistics" (June 2021, Eurostat), available at: <https://ec.europa.eu/eurostat/statistics-explained/index.php?title=Enforcement_of_ immigration_legislation_statistics> (last accessed 15 December 2021).

111 S Carrera "Whose pact? The cognitive dimensions of the new EU Pact on Migration and Asylum" (CEPS Policy Insights no 2020/22, 25 September 2020), available at: <https:// www.ceps.eu/ceps-publications/whose-pact/> (last accessed 13 December 2021).

112 F Maiani "A 'fresh start' or one more clunker? Dublin and solidarity in the new pact" (20 October 2020) EU Immigration and Asylum Law and Policy Blog, available at: <http:// eumigrationlawblog.eu/a-fresh-start-or-one-more-clunker-dublin-and-solidarity-in-thenew-pact/> (last accessed 13 December 2021).

113 A Dimitriadi "If you can dream it, you can do it? Early thoughts on the New Pact on Migration, and the impact on frontline states" (Hellenic Foundation for European \& Foreign Policy policy brief no 132/2020, September 2020) at 3-5, available at: <https:// www.eliamep.gr/en/> (last accessed 15 December 2021). 
The notion of mandatory "flexible solidarity" that has been introduced by the New Pact is an expression of intergovernmentalism, leading to fragmentation in European cooperation and going against the notion that "the enjoyment of equal rights and benefits stemming from membership in the EU carr[ies] similarly equal responsibilities". ${ }^{114}$ This flexibility might attract the approval of the opposing member states, but at the cost of weakening the possibility of a truly harmonized CEAS and, instead, creating an asylum system of asymmetric interstate solidarity. ${ }^{115}$

\section{CONCLUSIONS: THE GLOBAL COMPACT FOR REFUGEES IS A DIFFICULT BUT NECESSARY STEP IN RESHAPING THE CONCEPT OF SOLIDARITY IN AFRICA AND EUROPE}

According to Gilbert, "while the Refugee Compact is non-binding, it cannot be wholly divorced from a series of pre-existing international obligations by which States are bound". 116 However, as has been emphasized, "not all States are parties to all the relevant treaties, and even where they are, the rights may be restricted more than one would want in terms of providing better protection and assistance to refugees". 117 As illustrated in this research, regional mechanisms for refugee protection, such as those elaborated within the AU and the EU, can play a significant normative role in enhancing responsibility-sharing on the basis of a more binding legal set-up.

As regards the AU, it has been emphasized that the GCR drew inspiration from the OAU Convention principle of "solidarity and international cooperation". ${ }^{118}$ Nonetheless, despite providing a "strong platform for building common understandings and approaches", 119 African states have not adopted a common position on the GRC. However, the Migration Policy Framework for Africa (2018-30) and its Plan of Action are arguably aligned with the GRC's guiding principles, which "seek to operationalize the principle of responsibility-sharing to better protect and assist refugees and support host countries and communities". ${ }^{120}$ With the adoption of the GCR in 2018,

114 Carrera "Whose pact?", above at note 111 at 9.

115 T Pech and J-P Tran Thiet "New Pact on Migration and Asylum: Living up to our values" (29 September 2020, Institut Montaigne), available at: <https://www.institutmontaigne. org/en/blog/new-pact-migration-and-asylum-living-our-values> (last accessed 13 December 2021).

116 G Gilbert "Indicators for the Global Compact on Refugees" (2018) 30 International Journal of Refugee Law 635 at 636-37.

117 Ibid.

118 OAU Convention, art 2(4). See F Khan and C Sackeyfio "What promise does the Global Compact on Refugees hold for African refugees?” (2018) 30 International Journal of Refugee Law 696 at 697.

119 See O Dare and AM Abebe "Regional solutions and the Global Compact on Refugees: The experience from Africa” (2018) 30 International Journal of Refugee Law 704 at 705.

120 Carciotto and Ferraro "Building blocks and challenges", above at note 79 at 86. 
countries receiving large numbers of refugees can now be supported in a more predictable way through the expanded principle of responsibilitysharing in the GCR, ${ }^{121}$ especially through regional frameworks.

In Africa, regional and sub-regional action has been strengthened since the adoption of the New York Declaration and the GCR; worthy of mention is also the adoption of the Nairobi Declaration on Durable Solutions for Somali Refugees and Reintegration of Returnees in Somalia in the East Africa subregion. This sub-regional approach, the first of its kind, allows countries in the sub-region facing a refugee situation to work together to protect and find solutions for their plight, with support and assistance from the international community. ${ }^{122}$

Despite this laudable initiative, the success of such regional or sub-regional commitments depends on funding, without which these kinds of commitments to solidarity and responsibility-sharing will quickly run out of steam. ${ }^{123}$ This is the situation worldwide, particularly in Africa where the idea of solidarity and responsibility-sharing in the context of refugees is mainly associated with the physical sharing of refugees between states. In practice, this is rarely achieved. The GCR calls on African states to find more substantive and actionable approaches to the concept of responsibility-sharing through pooling financial and human resources and capacity through a multi-stakeholder, partnership approach or "whole-of-society" approach. This would include the involvement of local actors in both urban and rural settings, local authorities, networks of cities and municipalities hosting refugees, faith-based organizations, public-private partnerships, the UN system and global academic network on refugees ${ }^{124}$ to achieve the objectives set out in the GRC. These objectives cannot be achieved without financial resources. Therefore, in addition to access to asylum and the physical transfer of refugees, this article proposes that African states draw inspiration from the GCR's key tools for responsibility-sharing, including mechanisms for funding, and the effective and efficient use of resources in the African refugee context. The AU's Humanitarian Policy Framework ${ }^{125}$ needs to be refocused beyond the principle of "traditional African hospitality (Ubuntu)"; 126 it needs to be brought into line with the GCR recommendations, especially in the area of funding and support to specific refugee situations to ensure that the humanitarian and development nexus of the policy is further strengthened to ensure

121 GCR, para 4(c) states: “(i) ease pressures on host countries; (ii) enhance refugee selfreliance; (iii) expand access to third country solutions; and (iv) support conditions in countries of origin for return in safety and dignity".

122 Carciotto and Ferraro "Building blocks and challenges", above at note 79 at 48.

123 Nairobi Declaration, para IV (introducing the concept of pooling resources to tackle refugee situations) does not specify how member states should mobilize the resources.

124 See GCR, paras 14-18.

125 AU Humanitarian Policy Framework (20 November 2015).

126 Id, para 47. 
that the conditions in places of asylum and even places of return are safe and dignified for returning refugees.

As recommended in the GCR, pledges and contributions could take different forms, including financial, material and technical assistance, resettlement places and complementary pathways for admission to third countries. ${ }^{127}$ From this perspective, the EU offers great potential to contribute to the GCR's objectives. However, a reversal of trends is necessary to achieve these objectives successfully. First, it is pivotal that the CEAS is made accessible and the right to apply for asylum is possible. ${ }^{128}$ This requires a departure from the current paradigm of externalization that is predominant in the elaboration of this policy area. ${ }^{129}$ Safe channels for arrivals are necessary and constitute a major step towards the realization of the GCR objectives. ${ }^{130}$ Secondly, a more robust resettlement programme must be established under EU law as a contribution to the Global Refugee Forum and the model of solidarity and responsibility-sharing it envisages. Finally, technical and financial assistance should be injected through EU agencies and fairly allocated where necessary. ${ }^{131}$ Naturally, these steps must be complemented by adequate forms of control, transparency and accountability, aimed at ensuring a future-proof CEAS in line with human rights standards.

In conclusion, while acknowledging that the GCR is not a binding instrument, it does give an avenue for states, regional and sub-regional bodies to make commitments through pledges in the Global Refugee Forum. The GCR requires the political will of states, first to make tangible pledges and secondly to remain committed to fulfilling their pledges. It moreover requires the committed eyes of regional bodies to support and act as watchdogs to observe and provide advice to states.

\section{CONFLICTS OF INTEREST}

None

127 GCR, para 18

128 In this connection, see extensively V Moreno-Lax Accessing Asylum in Europe: Extraterritorial Border Controls and Refugees (2017, Oxford University Press).

129 See S Carrera, J Santos Vara and T Strik (eds) Constitutionalising the External Dimensions of EU Migration Policies in Times of Crisis. Legality, Rule of Law and Fundamental Rights Reconsidered (2019, Edward Elgar).

130 L Leboeuf "Legal pathways to protection: Towards a common and comprehensive approach?" (3 December 2020) EU Immigration and Asylum Law and Policy Blog, available at: <https://eumigrationlawblog.eu/legal-pathways-to-protection-towards-a-commonand-comprehensive-approach/> (last accessed 13 December 2021).

131 D Fernández-Rojo EU Migration Agencies. The Operation and Cooperation of FRONTEX, EASO and EUROPOL (2021, Edward Elgar). 